\title{
Corchorusolitoriuswaste(mulukiya) as a potential sorbent for the removal of cadmium (II) andthorium (IV) ions: kinetics, equilibrium study and image analysis
}

\author{
A. A. EMAM

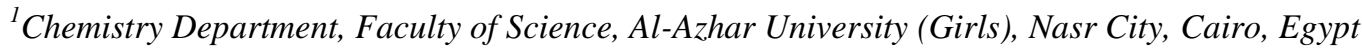

\begin{abstract}
This work was conducted to determine the practicability of using a new adsorbent Corchorusolitorius(mulukiya)waste,for the removal of cadmium (Cd(II)), and thorium (Th(IV)) from wastewater. Corchorusolitoriuswereanalysis by Fourier transform infraredFTIR, scanning electron microscopy (SEM) and energy dispersive X-ray Spectroscopy (EDEX). Some parameters such as adsorbent dosage, solution $p H$ 's, initial metal ion concentrations, and contact time, that influence adsorption phenomenon, were studied. The optimum $\mathrm{pH}$ for maximum adsorption of $\mathrm{Cd}(\mathrm{II})$ and $\mathrm{Th}(\mathrm{IV})$ was found to be 5.55 and 4.50, respectively. The contact time required for reaching equilibrium was $2 \mathrm{hr}$. The pseudo secondorder kinetic model was the best fit to represent the kinetic data. Analysis of the equilibrium adsorption data using Langmuir and Freundlich models showed that theLangmuir model was well suitable to describe the metal ions adsorption.
\end{abstract}

Keywords:Corchorusolitoriuswaste; Cadmium(II); Thorium(IV); Adsorption.

\section{Introduction}

The discharge of radioactive waste into the environment is a major issue. A radioactive material, is an environmental pollutant, being present in mining industry wastewater. Other sources include mainly soils and seawater (Rao et al., 2006).Thorium is abundantly available radioactive element in earth's crust in association with rare earths and uranium. The main sources of thorium are monazite, rutile and thorianite. It occurs in the tetravalent form in its compounds in nature. Also occurs naturally in ocean. The recent attention to extract thorium from waste streams is due to its application as a good fertile nuclear fuel for breeder reactors. It is extensively used in variable areas, such as optics, radio, aeronautics and aerospace, metallurgy and chemical industry, nuclear industry and material fields (Zhang et al., 2005).The existence of thorium in the nature and its potential use in the nuclear technology were not considered with sufficient importance because of the geological availability of natural resources of thorium and uranium. Thorium is an important component of the fuel in nuclear breeder reactors and thorium fuel cycle can be used in most of the reactors already operated (Raje and Reddy, 2010; Unak, 2000). On the verge of energy crisis, world has been utilizing maximum of its nuclear energy resources by extracting radioactive metals like uranium, thorium etc. Nuclear waste at a thorium-based reactor is minimal, and the plutonium from the process is used for further generation (Unak, 2000). Since thorium ions are radioactive, they emit electromagnetic radiations that can give permanent damage to cells and ultimately resulting to cancer.

Heavy metals are often detected in industrial wastewaters, which originate from metal plating, mining activities, smelting, battery manufacture, tanneries, petroleum refining, paint manufacture, pesticides, pigment manufacture, printing and photographic industries, etc. (Kadirvelu et al,2001, Williams et al,1998). Presence of metal ions is of specialconcern as they can accumulate in different components of the environment; represent a serious threat to human populations, the fauna, etc. $\mathrm{Cd}(\mathrm{II})$ is one of the most toxic metals. The cadmium has been well recognized for its negative effect on the environment where it is non-degradable and accumulates readily in living systems.Adverse health effects due to cadmium are well documented and it has been reported to cause renal disturbances, lung insufficiency, bone lesions, cancer and hypertension in humans ( Parker, 1980).

A number of technologies for removing cadmium and thorium ions from wastewaterhave been developed. The most important of these techniques include chemicalprecipitation, solvent extraction, adsorption, ion-exchange, and reverse osmosis. Adsorption is a relatively simple, cheap and effective method for wastewater treatment.Different adsorbents have been reported in the literature for the removal of U(VI) and $\mathrm{Th}(\mathrm{IV})$ ions, such as cellulose triacetate (Villalobos-Rodr'1guez et al., 2012), magnetic chitosan composite (Hritcu et al., 2012) and sepiolites (Kilislioglu and Aras, 2010).

A special attention has been focused on the use of natural adsorbents as an alternative to replace the conventional adsorbents, based on both the environmental and the economical points of view (Bable, 2003). Natural materials that are available in large quantities, or certain waste products from industrial or agricultural 
operations, may have potential as inexpensive sorbents. Due to their low cost, when these materials the end of their lifetime, they can be disposed of without expensive regeneration. The abundance and availability of agricultural by-products make them good sources of raw materials for natural sorbents.

Corchorusolitorius Linn is an important fiber crop cultivated in the Gangetic plane of West Bengal, India and Egypt. Jute plants produce edible leaves that are used as a vegetable and food constituent common to the people. It is made into a slimy soup or sauce in some of West African cooking traditions. Furthermore, it is also a popular dish in the northern provinces of the Philippines, also known as saluyot(Oboh et al., 2012).

The objective of the present work was to study the adsorption characteristics of cadmium (Cd(II)), and thorium (Th(IV)) ions from aqueous solution using Corchorusolitorius (mulukiya). The Langmuir andFreundlich and models were used to describe equilibrium isotherms. The kinetic data were fitted by models including pseudo-first-order and pseudo-second-order.

\subsection{Materials}

\section{Materials and methods}

All chemicals and reagents needed in the present study were of analytical grade and purchased from Merck. Solutions of Cadmium and thorium were prepared from $\mathrm{Cd}\left(\mathrm{NO}_{3}\right)_{2} \cdot 5 \mathrm{H}_{2} \mathrm{O}$ and $\mathrm{Th}\left(\mathrm{NO}_{3}\right)_{2} \cdot 5 \mathrm{H}_{2} \mathrm{Oby}$ dissolving appropriate amounts of salts in double distilled water. The stock solution was diluted with distilled water to obtain the desired concentration.

Corchorusolitorius (Fig.1) were collected from Elsharkiacity( Egypt). The raw materials (stems of Corchorusolitorius) were washed thoroughly with deionized water, and dried at $100 \circ \mathrm{C}$, crushed and sieved to particles with size range of 40-60 mesh for use as adsorbent

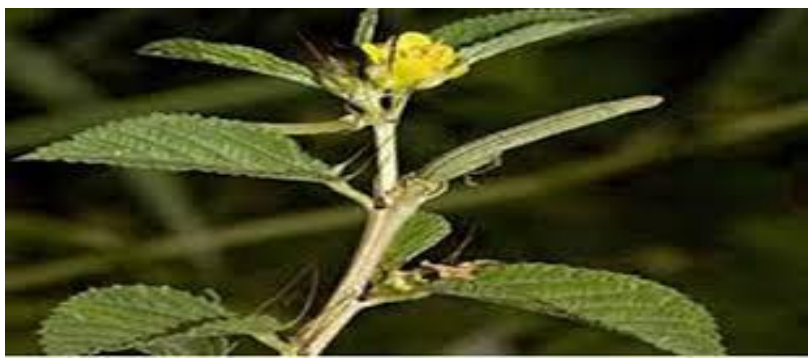

Fig. 1- Photo of Corchorusolitoriusleaves.

The Corchorusolitorius belongs to the class of condensed tannins which are the polymerized products of flavan-3-ols and/or flavan-3,4-diols and are the polyphenols with molecular weight of 500-3000 Da (Pizzi, 1993). The branch-chained tetraflavonoid structures of Corchorusolitorius have reactive and accessible nucleophilic centers in the rings (Fig. 2)(Aparna.,et al (2013).<smiles>COc1ccc2c(c1)OC(c1cc(O)c(O)c(O)c1)C(O)C2c1c(O)c(C2c3ccc(O)cc3OC(c3cc(O)c(O)c(O)c3)c3ccc(O)cc32)c(O)c2c1OC(c1cc(O)c(O)c(O)c1)C(O)C2c1cc(O)c(O)c(O)c1</smiles>

Fig. 2.Branch-chained tetraflavonoid structure of Corchorusolitoriusunit.

\subsection{Analysis}

The FT-IR spectra of the samplewere taken using a Shimadzu FT-IR spectrophotometer between 4000 and $500 \mathrm{~cm}^{-1}$ with $\mathrm{KBr}$ background. The Corchorusolitoriuswas done using Thermo Finnigan Flash EA IIIZ CHNS analyzer. 
Thesurface morphology of Corchorusolitorius and Cd(II) and Th(IV)adsorbed onto Corchorusolitorius samples examined using (JEOL SEM - 25) scanning electron microscope. Prior to examination, the samples were dried under sputter coated gold.

The energy dispersive X-ray (EDEX )pattern of Corchorusolitorius and Cd(II) and Th(IV)adsorbed onto Corchorusolitoriususing Oxfordenergy dispersive X-ray spectroscopy.

\subsection{Adsorption experiments}

Glass-stoppered Erlenmeyer flasks were used for adsorption experiments. Batch mode adsorption studies were conducted to study the effects of dose, equilibrium time, initial metal ion concentrations, and $\mathrm{pH}$. All experiments were carried out at $25^{\circ} \mathrm{C}$. A known amount of adsorbentwas continuously shaken in $50 \mathrm{~mL}$ of the corresponding salt solutions. Shaking was kept at $300 \mathrm{r} / \mathrm{min}$ for $2 \mathrm{hr}$ to reach equilibrium. After attaining the equilibrium, the adsorbent was removed by filtration and the concentrations of $\mathrm{Cd}(\mathrm{II})$ and $\mathrm{Th}(\mathrm{IV})$ ions in the corresponding filtrate were determined.

\subsection{Metal analysis}

The concentration of $\mathrm{Cd}(\mathrm{II})$ and $\mathrm{Th}(\mathrm{IV})$ ions was determined by AAS method. The difference in concentrations was taken as the amount adsorbed by Corchorusolitorius. An atomic adsorption spectrometer (Solaar M6, USA), with lead hallow cathode lamp and air acetylene flame.

The amount of metal ions adsorbed at equilibrium, $q_{\mathrm{e}}(\mathrm{mg} / \mathrm{g})$, was obtained by Eq. (1):

$q_{e}=\frac{\left(C_{e}-C_{e}\right) x V}{m}(\mathbf{1})$

where, $C_{0}(\mathrm{mg} / \mathrm{L}), C_{\mathrm{e}}(\mathrm{mg} / \mathrm{L})$ are the initial and equilibrium concentrations of the metal ion respectively, $V(\mathrm{~L})$ is the volume of solution, and $m(\mathrm{~g})$ is the mass of the adsorbent. Each experiment was carried out in duplicate and the average value is reported.

Solution $\mathrm{pH}$ was measured with a $\mathrm{pH}$ Meter (model $\mu$-362). All the solutions,for the adsorption equilibrium studies, were shaken at $25^{\circ} \mathrm{C}$ controlled by water bath shaker purchased from Labline, India.

\subsection{Characterization of adsorbent:}

\section{Results and discussion}

\subsubsection{Energy dispersive X-ray (EDEX )analysis}

The elucidation of $\mathrm{Cd}(\mathrm{II})$ and $\mathrm{Th}(\mathrm{IV})$ adsorption on the Corchorusolitorius were done by energy dispersive X-ray (EDEX) analysis. (EDEX) spectrum of Corchorusolitorius before and after interaction with metal ions is shownFig.3(a) (b) and (c).The spectrum of adsorbent presented in Figure 3(a )and Table (1) show that the major elements present. The EDX spectrumfor Corchorusolitoriusparticles indicated the presence of some element in the Table (1) but did not show the characteristic signal of $\mathrm{Cd}(\mathrm{II})$ and $\mathrm{Th}(\mathrm{IV})$ ions on the surface .The interaction between Corchorusolitorius with $\mathrm{Cd}(\mathrm{II})$ and Th(IV) are depicted in Fig.3 (b) and (c). An additional signal comparedwith the control onesFig.3 (a) observed in EDEX

profile(b) and (c)suggesting the interactionof metal with functional groups present in adsorbent. The EDX spectrum gives the characteristic peaks for $\mathrm{Cd}(\mathrm{II})$ and $\mathrm{Th}(\mathrm{IV})$. This confirms the binding of the metal ions to the Corchorusolitorius surface. The spectra reflectedTh(IV)with a high adsorption than $\mathrm{Cd}(\mathrm{II})$.

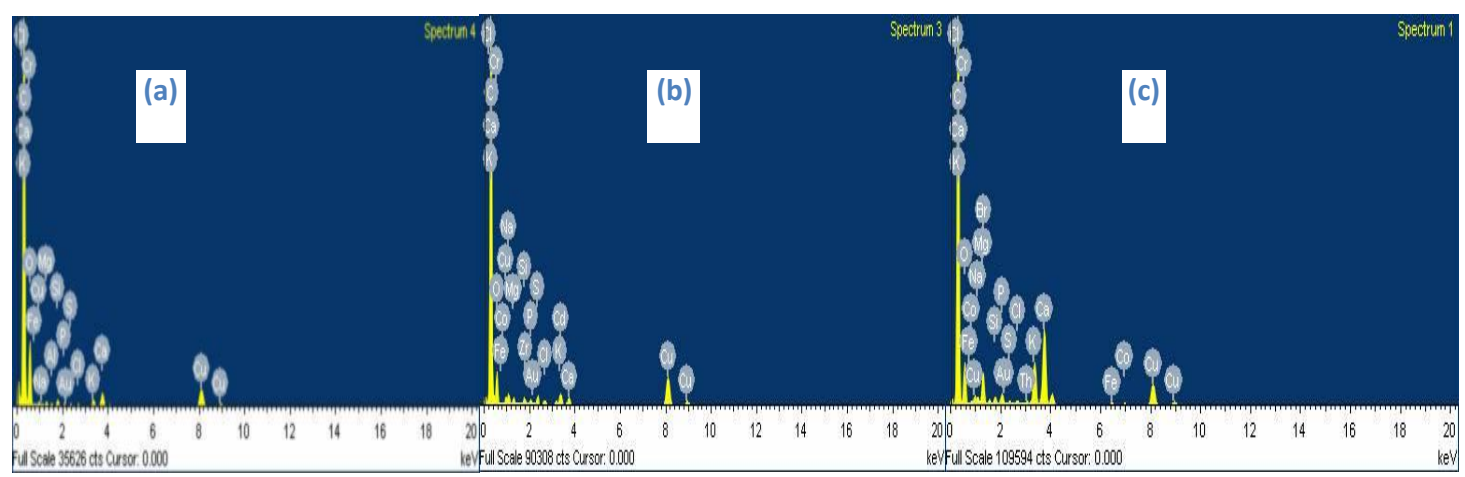

Fig. 3. EDEX Spectra of (a) Corchorusolitorius (b) Cd (II)-Corchorusolitorius (c) Th (IV) Corchorusolitorius. 
Table1. Weight \% of (a) Corchorusolitorius (b) Corchorusolitorius with Cd(II) (c) Corchorusolitorius with Th(IV).

\begin{tabular}{|c|c|c|c|c|c|}
\hline \multicolumn{2}{|c|}{ Corchorusolitorius } & \multicolumn{2}{|c|}{ Cd-Corchorusolitorius } & \multicolumn{2}{|c|}{ Th-Corchorusolitorius } \\
\hline Element & Weight \% & Element & Weight \% & Element & Weight \% \\
\hline $\mathbf{C}$ & 22.73 & $\mathbf{C}$ & 20.64 & $\mathbf{C}$ & 19.07 \\
\hline $\mathbf{N}$ & 1.45 & $\mathbf{N a}$ & 0.22 & $\mathbf{N a}$ & 0.20 \\
\hline $\mathbf{N a}$ & 0.08 & Mg & 0.39 & Mg & 1.26 \\
\hline Mg & 0.19 & Al & 0.17 & $\mathbf{S i}$ & 0.28 \\
\hline Al & 0.05 & $\mathbf{S i}$ & 3.36 & $\mathbf{P}$ & 0.62 \\
\hline $\mathbf{S i}$ & 0.10 & $\mathbf{P}$ & 0.15 & $\mathbf{S}$ & 0.23 \\
\hline $\mathbf{P}$ & 0.23 & $\mathbf{S}$ & 0.28 & Cl & 0.20 \\
\hline $\mathbf{S}$ & 0.37 & Cl & 0.17 & $\mathbf{K}$ & 3.75 \\
\hline Cl & 0.18 & $\mathbf{K}$ & 1.06 & Ca & 7.22 \\
\hline $\mathbf{K}$ & 0.39 & $\mathbf{C a}$ & 1.18 & $\mathrm{Cr}$ & 0.09 \\
\hline $\mathrm{Ca}$ & 0.80 & $\mathrm{Cr}$ & 0.06 & $\mathbf{F e}$ & 0.37 \\
\hline $\mathrm{Cr}$ & $\begin{array}{l}0.00 \\
0.05\end{array}$ & $\mathrm{Fe}$ & 0.00 & Co & 0.24 \\
\hline $\mathrm{Fe}$ & $\begin{array}{l}0.05 \\
0.08\end{array}$ & Fe & 0.40 & $\mathrm{Cu}$ & 6.75 \\
\hline $\mathrm{Cu}$ & $\begin{array}{l}0.00 \\
5.53\end{array}$ & Cu & 8.28 & $\mathrm{Br}$ & 0.24 \\
\hline Cu & 5.53 & Cd & 0.59 & $\mathbf{A u}$ & 0.04 \\
\hline Au & 0.07 & Au & 0.10 & Th & 0.60 \\
\hline $\mathbf{O}$ & 67.69 & $\mathbf{O}$ & 62.94 & 0 & 58.83 \\
\hline Totals & 100.00 & Totals & 100.00 & Totals & 100.00 \\
\hline
\end{tabular}

\subsubsection{Scanning electron microscopic(SEM) analysis}

The scanning electron micrographs (SEM) of Corchorusolitoriusbefore and after adsorptionCd(II) and Th(IV) are shown in (Fig. 4(a),(b) and (c)).The surface morphology revealed that a significant change inthe surface topography of Corchorusolitorius after metal adsorption. The surfaceof raw Corchorusolitorius was smooth with multicellular nature, whereasrough surface morphology with fragments and groove like structureswas observed due to adsorbed of $\mathrm{Cd}(\mathrm{II})$ and $\mathrm{Th}(\mathrm{IV})$.Moreover, it was also observedthat the natural green color of Corchorusolitorius had become dark green after adsorption.

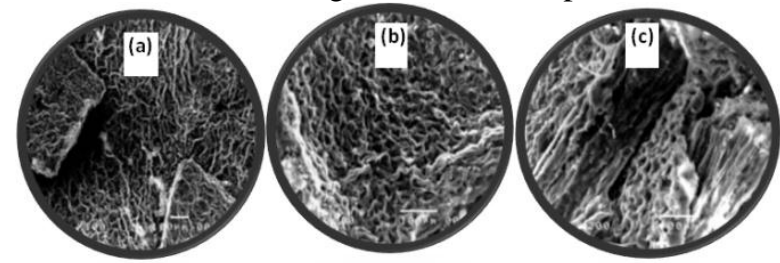

Fig. 4. SEM images of (a) Corchorusolitorius (b) Cd(II)-Corchorusolitorius (c) Th(IV) Corchorusolitorius.

\subsubsection{Fourier transform infrared (FTIR) spectroscopy}

Fig.5(a),(b) and (c)) presents the FT-IR spectra of Corchorusolitorius,Cd(II)-Corchorusolitoriusand Th(IV)- Corchorusolitorius respectively. The FTIR spectra of a,b,c, showed a broad band in the region of 3700 $3010 \mathrm{~cm}^{-1}$, which is due to the characteristic $-\mathrm{OH}$ stretching for phenolic or alcoholic group. The smaller peak at $2927 \mathrm{~cm}^{-1}$ is associated with the $-\mathrm{CH}$ stretchingof the aromatic rings andmethylene $\left(-\mathrm{CH}_{2}-\right)$ bridges. The peak at $1611 \mathrm{~cm}^{-1}$ corresponds to the characteristic elongation of aromatic $-\mathrm{C}=\mathrm{C}-$ bonds. The deformation vibration of $-\mathrm{C}-\mathrm{C}-$ bonds in the phenolic group absorbs in the region of $1510-1400 \mathrm{~cm}^{-1}$. The peak at 1454 $\mathrm{cm}^{-1}$ may be assigned to bending. The signal at $1345 \mathrm{~cm}^{-1}$ is associated with the $-\mathrm{OH}$ deformation vibration for phenolicor alcoholic group. The absorption peak at around $1232 \mathrm{~cm}^{-1}$ is associated with the $-\mathrm{CO}$ stretching of aromatic ring. The ant symmetric $-\mathrm{C}-\mathrm{O}-\mathrm{C}-$ stretching contributes for the peak at $1159 \mathrm{~cm}^{-1}$. The bands in therange of $843-665 \mathrm{~cm}^{-1}$ are attributed to the deformation vibrationsof the $\mathrm{C}-\mathrm{H}$ bond in the aromatic rings (Sanchez-MartGnaGonzalez-Velasco, Beltran-Heredia, Gragera-Carvajal, \&Salguero-Fernandez, 2010).The peak at $898 \mathrm{~cm}^{-1}$ for $\beta$-glucosidic linkage of cellulose in Corchorusolitorius.It was also observed that new peak at $556 \mathrm{~cm}^{-1}$ due to adsorbed of $\mathrm{Cd}(\mathrm{II})$ and Th(IV) onto Corchorusolitorius (Fig. 5(b) and (c)). 


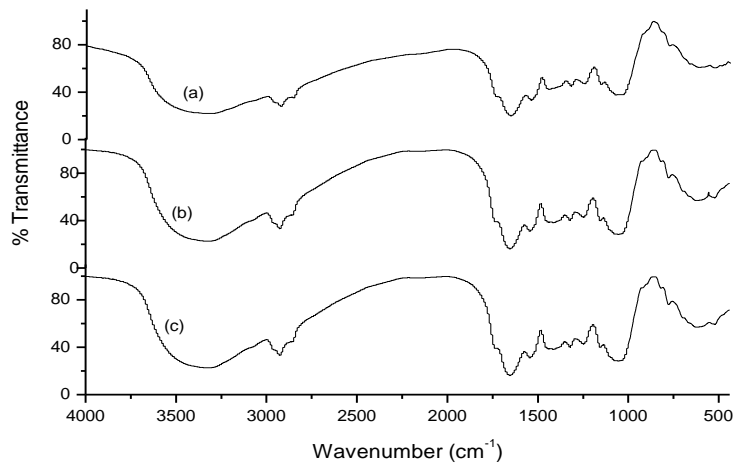

\section{Fig. 5. FTIR spectra of(a) Corchorusolitorius (b) Cd(II)-Corchorusolitorius (c) Th(IV) Corchorusolitorius.}

\subsection{Effect of $\mathbf{p H}$}

The $\mathrm{pH}$ level is one of the important parameters for the adsorption of metal ions from an aqueous solution. The $\mathrm{pH}$ of the solution will affect the surface charge of the adsorbent and the degree of ionization. The effect of $\mathrm{pH}$ on the adsorption of $\mathrm{Cd}(\mathrm{II})$ and $\mathrm{Th}(\mathrm{IV})$ onto Corchorusolitorius at different initial concentrations $(30.0,50.0,70.0$ and $100.0 \mathrm{mg} / \mathrm{L})$ at $25^{\circ} \mathrm{C}$ is depicted in Fig. 6.It can be seen that the adsorption percentages are very low at strong acidicmedium. The minimal adsorption at low $\mathrm{pH}$ may be due to the higher concentration and high mobility of $\mathrm{H}^{+}$, which are preferentially adsorbed rather than metal ions (Ajmal et al.,2000,Annadurai et al.,2002).Increasing the $\mathrm{pH}$ ofthe solution, the lower number of $\mathrm{H}^{+}$(results in more metal ionsadsorption.Adsorption of increased sharply with increase of $\mathrm{pH}$ up to optimum $\mathrm{pH} 5.55$ and 4.50 for $\mathrm{Cd}(\mathrm{II})$ and $\mathrm{Th}(\mathrm{IV})$ respectively then started decreasing. Therefore, all the following experiments were performed at these optimum $\mathrm{pH}$. The higher dsorptionTh(IV) at $\mathrm{pH} 4.50$ could be associated with the predominance of $\left[\mathrm{Th}_{2}(\mathrm{OH})^{2}\right]^{6+}$ and other polymerized species possessing a better bindingaffinity (Tsezos and Volesky, 1982). Adsorption was limited above $\mathrm{pH} 6.0$ due to the formation of neutral $\mathrm{Th}(\mathrm{OH})_{4}$.
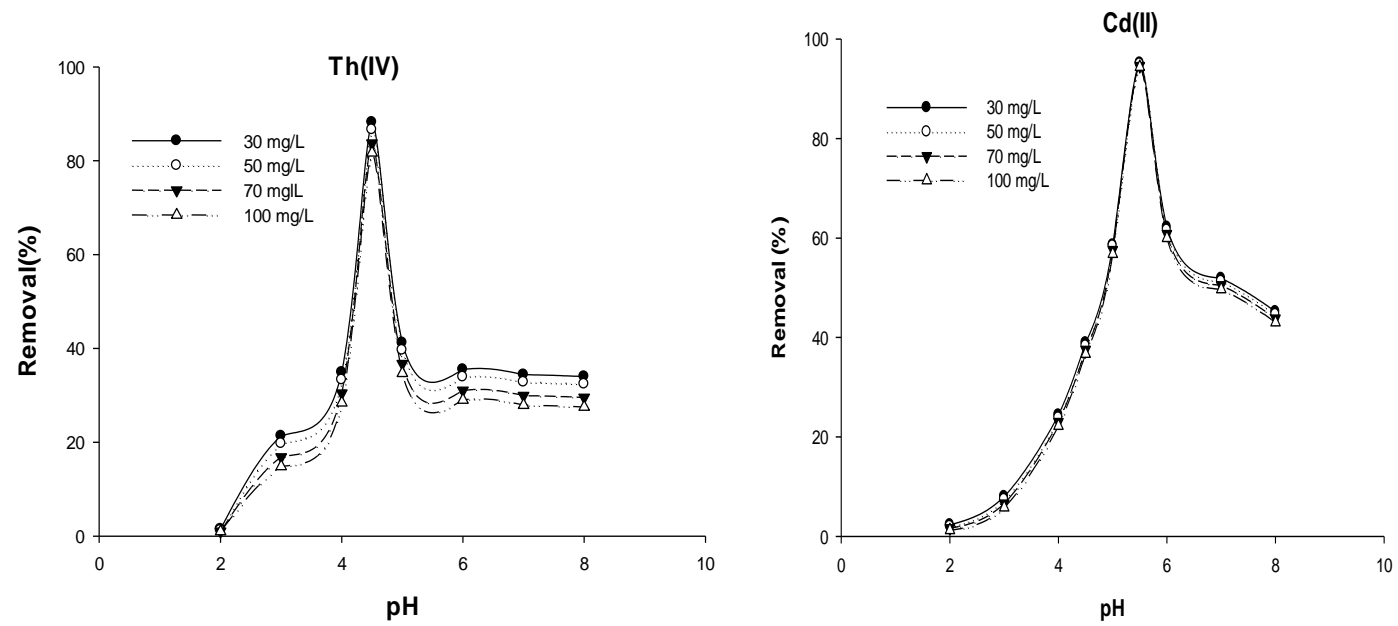

Fig. 6Effect of $\mathrm{pH}$ on the adsorption of $\mathrm{Cd}(\mathrm{II})$ and $\mathrm{Th}(\mathrm{IV})$ onto Corchorusolitorius. Conditions: adsorbent dose $0.01 \mathrm{~g} / \mathrm{L}$; equilibrium time $4 \mathrm{hr}$; temperature $25^{\circ} \mathrm{C}$.

\subsection{Effect of adsorbent dose}

The effect of adsorbent dose on the removal of Cd(II) andTh(IV) ions was studied by carrying out the adsorptionexperiments using various amounts of Corchorusolitoriusat the optimum $\mathrm{pH} 5.55$ for $\mathrm{Cd}$ (II) and 4.5 for $\mathrm{Th}(\mathrm{IV})$ at $25^{\circ} \mathrm{Cwith}$ varying initial metal ion concentration of $\mathrm{Cd}(\mathrm{II})$ and $\mathrm{Th}(\mathrm{IV}) 30,50,70$ and $100 \mathrm{mg} / \mathrm{L}$ Th(IV) (Fig. 7). The time needed to attain equilibrium was taken as $4 \mathrm{hr}$. The removal percentage of Cd(II) andTh(IV) ions was noted as a function of adsorbent dose. Theremoval of metal ion increasedwith an increase of dose from 0.005 to $0.03 \mathrm{~g} / \mathrm{L}$. This can be due to the fact that, the active sites could be effectively utilized when the dosage was low. Asadsorbent dosage was increased, the number of unoccupiedeffective sites and the surface area also increased and thusit improved the percentage of adsorption. 

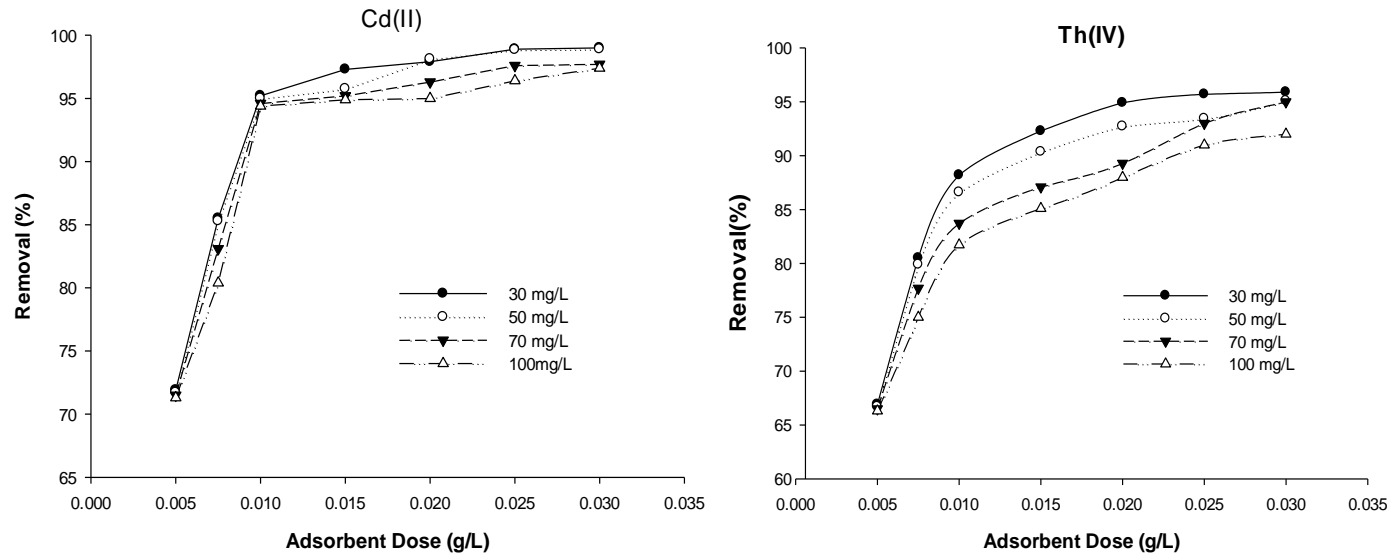

Fig.7Effect of adsorbent dose on the adsorption of $\mathrm{Cd}(\mathrm{II})$ and $\mathrm{Th}(\mathrm{IV})$ onto Corchorusolitorius. Conditions: equilibrium time $2 \mathrm{hr}$; concentrations; 30, 50.70, and $100 \mathrm{mg} / \mathrm{L} ; \mathrm{pH} 5.0$ for $\mathrm{Cd}(\mathrm{II}) ; \mathrm{pH} 4.5$ for Th(IV).

\subsection{Effect of contact time and initial concentration}

In order to establish an appropriate contact time between the adsorbent and metallic ions in solution, the adsorption of $\mathrm{Cd}(\mathrm{II})$ and $\mathrm{Th}(\mathrm{IV})$ onto Corchorusolitoriuswas tested as a function of contact time at different initial concentrations (30 to $100 \mathrm{mg} / \mathrm{L}$ ) of metal ion solutions . Fig. 8illistrated thatthe rate of adsorption for $\mathrm{Cd}(\mathrm{VI})$ and $\mathrm{Th}(\mathrm{IV})$ was initiallyfast and then reached a plateau value. The high adsorption rate was due to the abundance of active binding sites on the adsorbent, and as these sites get saturated, only a reduced amount of adsorption was occurred (da Costa and Leite, 1991). The equilibrium time was found to be a constant and was independent of the initial $\mathrm{Cd}(\mathrm{II})$ and $\mathrm{Th}(\mathrm{IV})$ ion concentrations.

The quantity of $\mathrm{Cd}(\mathrm{II})$ and $\mathrm{Th}(\mathrm{IV})$ ionsadsorbed at equilibrium onto Corchorusolitoriuswas found to be improved from 26.5 and $31.09 \mathrm{mg} / \mathrm{g}$ to 70.42 and $73.2 \mathrm{mg} / \mathrm{g}$, respectively, on increasing the initial concentration from 30 to $100 \mathrm{mg} / \mathrm{L}$ indicating that the metal removalwas concentration dependent. The increase of metal ion concentration accelerated the diffusion of metal ion from the bulk solution onto the adsorbent phase because of the enhanced force of the higher concentration (Hameed et al., 2008). If metal ion/adsorbent ratios are low, metal adsorption takes place at higher energy sites. When the metal ion/adsorbent ratio is increased, the higher energy sites become saturated and lower energy sites are involved in adsorption and consequently the adsorption efficiencyis decreased (Bhattacharya et al., 2006). Since the amount of metal ions adsorbed did not change after $2 \mathrm{hr}$, the succeeding adsorption experiments were done keeping $2 \mathrm{hr}$ as an appropriate equilibrium time.
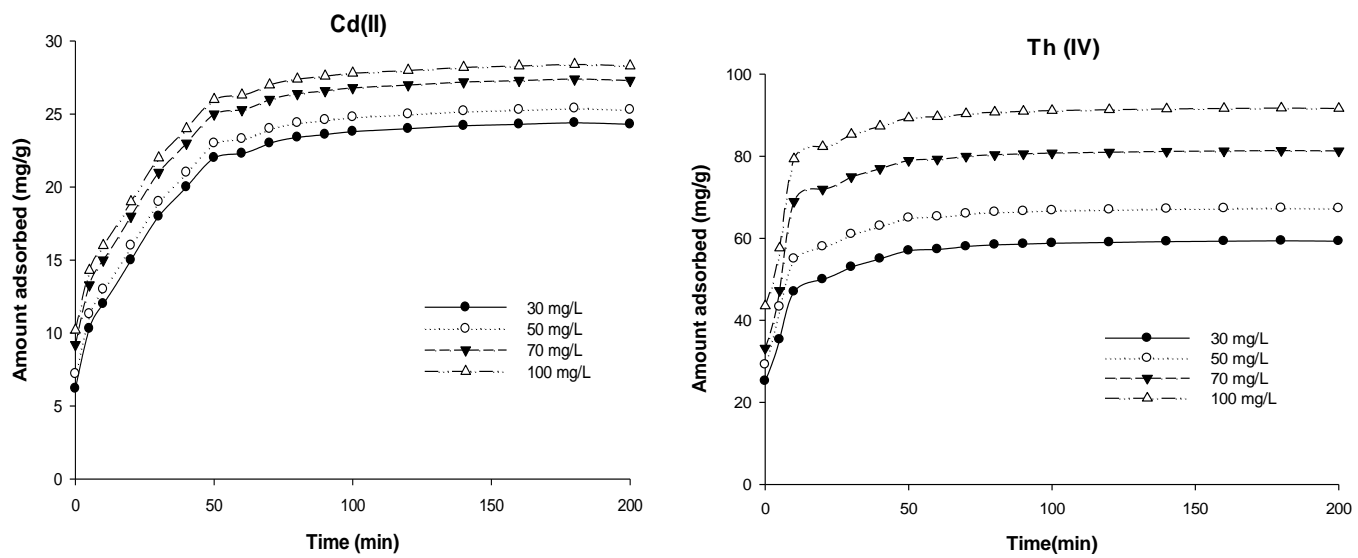

Fig. 8 Adsorption kinetics at different initial Cd(II) and Th(IV) concentrations $(30-100 \mathrm{mg} / \mathrm{L})$. Conditions: adsorbent dose $0.01 \mathrm{~g} / \mathrm{L} ; \mathrm{pH} 4.5$ for $\mathrm{Th}(\mathrm{IV}) ; \mathrm{pH} 5.0$ for $\mathrm{Cd}(\mathrm{II})$; temperature $25^{\circ} \mathrm{C}$.

\subsection{Adsorption kinetics}

Studies on the adsorption rate showed that the removal decreased with increased $\mathrm{Cd}(\mathrm{II})$ and $\mathrm{Th}$ (IV) concentrationFig. 8. The metal removal mechanism is related to the initial metal ion concentration. Adsorption of metal ions takes place at definite sites only when the metal ion concentration is low, but as the concentration is increased, the sites become saturated and exchange sites are filled (Patel et al., 2007).The maximum amount of $\mathrm{Cd}(\mathrm{II})$ and $\mathrm{Th}(\mathrm{IV})$ ions was adsorbed within the first $30 \mathrm{~min}(80-90 \%$ of total metal ions adsorbed) and 
thereafter the adsorption proceeded at a slower rate until equilibrium reached. The equilibrium time was found to be at $120 \mathrm{~min}$ for the initial concentration range studied. This might be attributed to extremely slow diffusion of the metal ions from the surface film into the microspores which are the least accessible sites for adsorption (Warhurst et al., 1997).

The kinetics of adsorption describes the rate of metal ions uptake onto the Corchorusolitorius and this rate control the equilibrium time. The kinetics of adsorbate uptake is required for selecting optimum operating conditions for the full-scale batch process, so these models are important inwater treatment process design. The kinetic parameter, whichis helpful for the prediction of adsorption rate, gives important information for designing and modeling the process. Thus, the effects of contact time at different concentration were analyzed from the kinetic point of view.

Adsorption kinetics are generally controlled by different mechanism, of which the most limiting are the diffusion mechanisms, including the initial curved portion, attributed to rapid external diffusion or boundary layer diffusion andsurface adsorption, and the linear portion, a gradual adsorption stage due to the intraparticle diffusion, followed by aplateau to the equilibrium where the intraparticle diffusion starts to decrease due to the low concentration in solution phase as well as fewer available adsorption sites (Guibaletal., 2003). Previously several researchers used different kinetic models, such as Lagergren's pseudo first order, pseudo second order, Elovich kinetic equation, and parabolic diffusion model, to represent the mechanism of the adsorption process (Hoda et al., 2006; Sarkar et al., 2006;Weber and Morris, 1963).

TheLagergren's pseudo first order and pseudo-second-order model has been widelyused for adsorption systems due to its good representation of the experimental data for most of the adsorbent-adsorbatesystems (Ho and McKay, 1999). The pseudo-second- order equation has the following advantages: it does not have the problem of assigning an effective adsorption capacity, the adsorption capacity, rate constant of pseudo-second order and the initial adsorption rate all can be determined from the equation without knowing any parameter beforehand.

The linear form of pseudo first order model can be expressedas:

$\log \left(q_{e}-q_{t}\right)=\log q_{e}-\frac{k_{1}}{2.303} \mathrm{t}$

where $\mathrm{q}_{\mathrm{e}}$ and $\mathrm{q}_{\mathrm{t}}\left(\mathrm{mg} \mathrm{g}^{-1}\right)$ are the adsorption capacities at equilibrium andattime $\mathrm{t}$ respectively

$\mathrm{k}_{1}$ at different concentration evaluated experimentally, were calculated using the slope and intercept of plots of $\log \left(\mathrm{q}_{\mathrm{e}}-\mathrm{q}_{\mathrm{t}}\right)$ versus $\mathrm{t}$, Table 2 . Best fit lines at each concentration yielded relatively high $\mathrm{R}^{2}$ values.

The pseudo second-order rate expression, which has been applied for analyzing sorption kinetics from liquid solutions, is linearly expressed as

$\frac{t}{q_{t}}=\frac{1}{k_{2} q_{e}^{2}}+\frac{1}{q_{e}} \mathrm{t}(3)$

where $\mathrm{k}_{2}$ is the rate constant for pseudo second-order adsorption $\left(\left(\mathrm{mgg}^{-1} \mathrm{~min}^{-1}\right)\right.$ and $k_{2} q_{e}^{2}$ or $\mathrm{h}$ is the initial sorption rate $\left(\mathrm{mgg}^{-1} \mathrm{~min}^{-1}\right) . k_{2}$ and $q_{e}$ can be obtained from the intercept and slope of plotting $\left(\mathrm{t} / q_{t}\right)$ versus $(\mathrm{t})$. where $h$ is the initial sorption rate $\left(\mathrm{mgg}^{-1} \mathrm{~min}^{-1}\right) ; k_{2}\left(\mathrm{mgg}^{-1} \mathrm{~min}^{-1}\right)$ is the second-order rate constant. $k_{2}$ and $q_{e}$ canbe obtained from the intercept and slope of plotting

$\left(\mathrm{t} / q_{t}\right)$ versus $(\mathrm{t})$. This model is more likely to predict the kinetic behavior of adsorption with chemical adsorption being the rate controlling step. The pseudo-second-order reaction is greatly influenced by the amount of metal on the adsorbent's surface and the amount of metal adsorbed at equilibrium (Ho and McKay, 1999).

Pseudo second-order adsorption parameter $\mathrm{k}_{2}$ were determined at different concentration and recorded in Table 2. Furthermore the correlation coefficients $\mathrm{R}^{2}$ for the pseudo second-order kinetic model fits are close 1.00 , higher than the correlation coefficients derived from pseudo first-order model fits. Given the good agreementbetweenmodelfitandexperimentallyobservedequilibriumadsorptioncapacityinaddition

to thelargecorrelationcoefficients, thissuggeststhat $\mathrm{Cd}(\mathrm{II})$ and $\mathrm{Th}(\mathrm{IV})$ adsorption followedpseudosecondorderkineticsand adsorbent ions were adsorbedontotheCorchorusolitoriusviachemicalinteraction. 

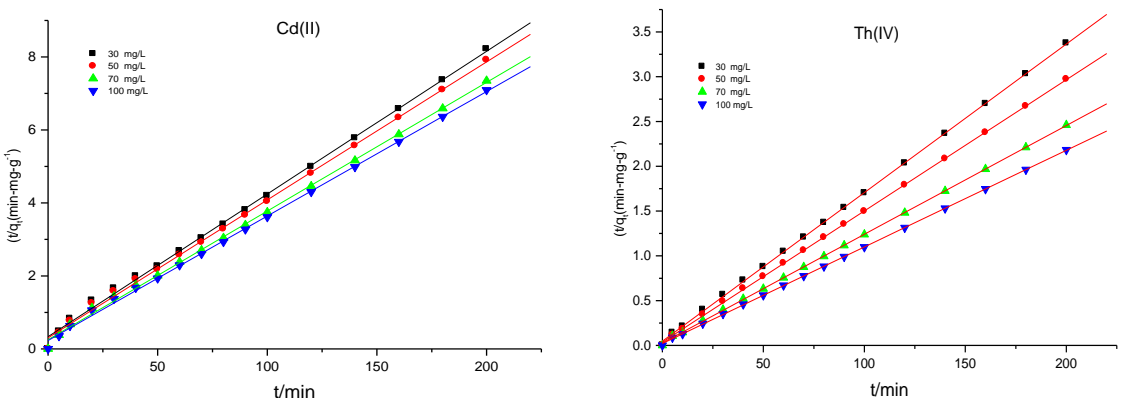

Fig. 9Pseudo-second-order kinetics model for $\mathrm{Cd}(\mathrm{II})$ and $\mathrm{Th}(\mathrm{IV})$ concentrations (30-100 mg/L)adsorption onto the Corchorusolitorius.

\begin{tabular}{|c|c|c|c|c|c|}
\hline \multirow{2}{*}{\multicolumn{2}{|c|}{ Concentration (mg/L) }} & \multicolumn{2}{|c|}{ Pseudo first -order } & \multicolumn{2}{|l|}{ Pseudo second -order } \\
\hline & & $k_{1}\left(\mathrm{x} 10^{-2} \mathrm{~min}^{-1}\right)$ & $\mathrm{R}^{2}$ & $k_{2}\left(\mathrm{x} 10^{-3} \mathrm{~g} /(\mathrm{mg} \cdot \mathrm{min})\right)$ & $\mathrm{R}^{2}$ \\
\hline \multirow[t]{4}{*}{$\mathrm{Cd}(\mathrm{II})$} & 30 & 8.86 & 0.993 & 4.59 & 0.998 \\
\hline & 50 & 7.82 & 0.994 & 4.72 & 0.999 \\
\hline & 70 & 7.59 & 0.992 & 4.64 & 0.999 \\
\hline & 100 & 8.28 & 0.995 & 5.06 & 0.999 \\
\hline \multirow[t]{4}{*}{ Th(IV) } & 30 & 8.88 & 0.984 & 5.73 & 0.999 \\
\hline & 50 & 8.94 & 0.982 & 5.92 & 0.999 \\
\hline & 70 & 9.24 & 0.970 & 5.47 & 0.999 \\
\hline & 100 & 9.93 & 0.974 & 5.64 & 0.999 \\
\hline
\end{tabular}

\subsection{Adsorption isotherm}

The adsorption data are usually collected in terms of the total amount of the adsorbate adsorbed at the adsorbent's surface. When the amount adsorbed at equilibrium is plotted against the equilibrium concentration of the adsorbateat constant temperature, adsorption isotherms are obtained. Since an adsorption isotherm gives an idea about the adsorption capacity of the adsorbent, this can be used for optimizing the application of an adsorbent. The common adsorption isotherm models are Langmuir and Freundlich, (Langmuir-Freundlich). These equations were tested to fit the experimental adsoption data of $\mathrm{Cd}(\mathrm{II})$ and $\mathrm{Th}(\mathrm{IV})$ ions. The Langmuir model suggests a monolayer adsorption onto the adsorbent having uniform surface sites with equivalent energies and the adsorbed species do not interact with one another (Langmuir, 1918). The Freundlich model is an empirical one relating adsorption onto heterogeneous surface (Freundlich, 1906). This model is typical of heterogeneous surfaces and suggests that thesurface active sites of the adsorbent have unequal binding energies.

Langmuir equation:

$q_{e}=\frac{Q^{0} \quad b_{L} C_{0}}{1+b_{L} C_{0}}(4)$

Freundlich equation:

$q_{e}=K_{F} C_{e}^{1 / n_{F}}(\mathbf{5})$

where, $q_{e}(\mathrm{mg} / \mathrm{g})$ is the amount adsorbed at equilibrium and $C_{0}(\mathrm{mg} / \mathrm{L})$ is the equilibrium concentration of the metal ions in solution. $Q^{0}$ and $b_{L}$ are Langmuir constants associated with adsorption capacity and binding energyof adsorption, respectively. $K_{F}$ and $1 / n_{F}$ represent Freundlich's constants connected to adsorption ability and the heterogeneity factor, respectively. The isotherms constants of $\mathrm{Cd}(\mathrm{II})$ and $\mathrm{Th}(\mathrm{IV})$ ions onto Corchorusolitoriusare illustrated in (Table 3). The $q_{e}$, was studied as a function of $C_{0}$. Based on the correlation coefficients (Table 3), the Langmuir equation gives a better fit of experimental data than the Freundlich, for the adsorption of $\mathrm{Cd}(\mathrm{II})$ and $\mathrm{Th}(\mathrm{IV})$ ions. This suggests a monolayer adsorption onto the adsorbent having uniform surface sites with equivalent energies, The Freundlichconstant $1 / n_{F}$ was below 1 at all the experimental concentrations,indicative of high adsorption intensity (Tsai et al.,2003). 
Table 3Various isotherm parameters for the adsorption of $\mathrm{Cd}(\mathrm{II})$ andTh(IV) onto Corchorusolitorius.

\begin{tabular}{|c|c|c|c|c|}
\hline \multicolumn{5}{|c|}{ Metal ionLangmuirFreundlich } \\
\hline Cd(II) & $Q^{0}$ & 95.55 & $K_{F}$ & 4.58 \\
& $b_{L}$ & 0.0121 & $1 / n_{F}$ & 0.007 \\
& $\mathbf{R}^{2}$ & 0.960 & $\mathbf{R}^{2}$ & $\mathbf{0 . 9 5 6 8}$ \\
Th(IV) & $Q^{0}$ & 44.94 & $K_{F}$ & 2.79 \\
& $b_{L}$ & 0.043 & $1 / n_{F}$ & 0.0372 \\
& $\mathbf{R}^{2}$ & 0.979 & $\mathbf{R}^{2}$ & 0.9755 \\
\hline
\end{tabular}

IV. Conclusions

Batch adsorption studies proved that the new adsorbent,Corchorusolitorius has high adsorption capacity for $\mathrm{Cd}(\mathrm{II})$ and $\mathrm{Th}(\mathrm{IV})$ ions in the $\mathrm{pH}$ range 4.0-6.0. Kinetics datafitted well with pseudo second-order model confirmingthe chemisorptions of the metal ions onto Corchorusolitorius.The adsorption equilibrium experiments matched wellwith the Freundlich isotherm model.The results of thiswork showed that the new adsorbent Corchorusolitoriuscan beeffectively used for the removal of metal ions from aqueoussolutions and other industrial effluents.

\section{References}

[1]. Rao T P, Metilda P, Gladis J M, 2006. Preconcentration techniques for uranium(VI) and thorium(IV) prior to analytical determination - an overview.

[2]. Talanta, 68(4): 1047-1064.15-S. Bable, T.A. Kurniawan,(2003). Low-cost adsorbent for heavy metals uptake from contaminated water; a review J. Hazard. Mater. 97, 219-243.

[3]. Zhang, S., Liu, P., Zhang, B., 2005.Thorium resources and their availability.World Nucl.Geosci.22, 98e103.Raje, N., Reddy, A.V.R., 2010. Mechanistic aspects of thermal decomposition of thorium oxalate hexahydrate: a review. Thermochim.Acta 505, $53 \mathrm{e} 58$.

[4]. Unak, T., 2000. What is the potential use of thorium in the future energy production technology? Prog.Nucl.Energy 37, 137e144.

[5]. Villalobos-Rodr'iguez R, Montero-Cabrera M E, Esparza-Ponce H E, Herrera-Peraza E F, Ballinas-CasarrubiasM L, 2012.Uranium removal from water using cellulose triacetate membranes added with activated carbon. Applied Radiationand Isotopes, 70(5): 872881.

[6]. Hritcu D, Humelnicu D, Dodi G, Popa M I, 2012. Magnetic chitosan composite particles: Evaluation of thorium anduranyl ion adsorption from aqueous solutions. Carbohydrate Polymers, 87(2): 1185-1191.

[7]. Kilislioglu A, Aras G, 2010. Adsorption of uranium from aqueous solution on heat and acid treated sepiolites.Applied Radiation and Isotopes, 68(10): 2016-2019.

[8]. Oboh, G., Ademiluyi, A.O., Akinyemi, A.J., Henle, T., Saliu, J.A., Schwarzenbolz, U.2012. Inhibitoryeffect of polyphenol-rich extracts of jute leaf (Corchorusolitorius) on key enzyme linked to type 2 diabetes (a-amylase and aglucosidase) and hypertension (angiotensin I converting) in vitro. J. Funct.Food. 4, 450-458.

[9]. Kadirvelu, K. Thamaraiselvi, K. Namasivayam, C. Removal of heavy metal from industrial wastewaters by adsorption onto activated carbon prepared from an agricultural solid waste, Bioresour. Technol.76 (2001) 63-65.

[10]. Williams, C.J. Aderhold, D. Edyvean, G.J. Comparison between biosorbents for the removal of metal ions from aqueous solutions, Water Res. 32 (1998) 216-224.

[11]. Parker, S. Encyclopedia of Environmental Science, second ed., McGraw-Hill,New York, 1980

[12]. Pizzi, A. (1993). Wood adhesives chemistry and technology New York: Marcel Dekker.

[13]. Sanchez-Martina, J., Gonzalez-Velasco, M., Beltran-Heredia, J., Gragera-Carvajal, J.,\&Salguero-Fernandez, J.

[14]. (2010). Novel tannin-based adsorbent in removing cationic dye (methylene blue) from aqueous solution.

[15]. Kinetics and equilibrium studies. Journal of Hazardous Materials, 174, 9-16.

[16]. Ajmal, M.; Rao, R.A.K.; Ahmad, R.; Ahmad, J. Adsorption studies on Citrus reticulata (fruit peeloforange): Removal and recovery of $\mathrm{Ni}(\mathrm{II})$ from electroplating wastewater. J. Hazard. Mater.2000, 79, 117-131.

[17]. Annadurai, G.; Juang, R.S.; Lee, D.J. Use of cellulose-based wastes for adsorption of dyes fromaqueous solutions. J. Hazard. Mater.2002, 92, 263-274.

[18]. Hameed B H, Mahmoud D K, Ahmad A L, 2008. Sorption equilibrium and kinetics of basic dye from aqueoussolution using banana stalk waste. Journal of Hazardous Materials,158(2-3): 499-506.

[19]. Tsezos M, Volesky B, 1982. The mechanism of thorium biosorption by Rhizopusarrhizus. And Bioengineering,24(4): 955-969

[20]. Da Costa A C A, Leite S G F, 1991. Metals biosorption by sodium alginate immobilized Chlorella homosphaeracells. Biotechnology Letters, 13(8): 559-562.

[21]. Bhattacharya A K, Mandal S N, Das S K, 2006. Adsorption of Zn(II) from aqueous solution by using differentadsorbents.Chemical Engineering Journal, 123(1-2): 43-51.

[22]. Patel M M, Kapadia M A, Patel G P, Joshi J D, 2007. Synthesis, characterization, ion-exchange and antimicrobial study of poly [(2hydroxy-4-methoxy benzophenone) ethylene] resin and its polychelates with lanthanides (III). Reactive and Functional Polymers, 67(8): 746-757.

[23]. Warhurst, A.M., Fowler, G.D. and McConnachie, G.L., 1997, Pore structure and adsorption characteristics of steam pyrolysis carbons from Moringaoleifera. Carbon, 35: 1039-1045.

[24]. Tsezos M, Volesky B, 1982. The mechanism of thorium biosorption by Rhizopusarrhizus. Biotechnology and Bioengineering, 24(4): 955-969.

[25]. Guibal, E., McCarrick, P. and Tobin, J.M., 2003, Comparison of the sorption of anionic dyes on activated carbon and chitosanderivatives from dilute solutions. Sep. Sci. Technol., 38: 3049-3073.

[26]. Hoda, N., Bayram, E. and Ayranci, E., 2006, Kinetic and equilibrium studies on the removal of acid dyes from aqueoussolutions by adsorption onto activated carbon cloth. J. Hazard. Mater., B137: 344-351.

[27]. Ho Y S, McKay G, 1999. Pseudo-second-order model for sorption processes. Process Biochemistry, 34(5): 451- 465.

[28]. Freundlich H M F, 1906. U“" ber die adsorption in lo“sungen.Zeitschrift fur PhysikalisChemie, 57: 385-470. Langmuir I, 1918.The adsorption of gases on plane surfaces of glass, mica and platinum. Journal of the AmericanChemical Society, 40(9): 1361-1403. 
[29]. Tsai W T, Lai C W, Hsien K J, 2003. Effect of particle size of activated clay on the adsorption of paraquat from aqueous solution. Journal of Colloid and Interface Science, 263(1): 29-34.

[30]. Bable, S. Kurniawan, T.A. (2003). Low-cost adsorbent for heavy metals uptake from contaminated water; a review J. Hazard. Mater. 97, 219-243.

[31]. Aparna, R., Sumit, C., Sarada, P. K., Subhasish, B. M., Basudam A., Surface grafting of Corchorusolitoriusfibre: A green approach for the development of activated bioadsorbent, J.Carbohydrate Polymers 92 (2013) 2118-2127. 